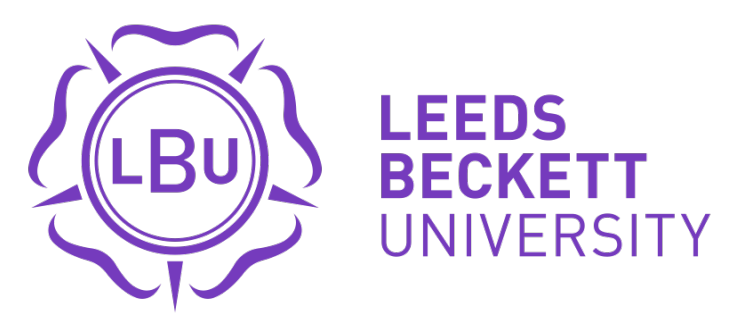

Citation:

Craig, J (2019) The Emergence of Politics as a Taught Discipline at Universities in the UK. British Journal of Politics and International Relations. ISSN 1369-1481 DOI: https://doi.org/10.1177/1369148119873081

Link to Leeds Beckett Repository record:

https://eprints.leedsbeckett.ac.uk/id/eprint/6259/

Document Version:

Article (Accepted Version)

Creative Commons: Attribution-Noncommercial-No Derivative Works 4.0

The aim of the Leeds Beckett Repository is to provide open access to our research, as required by funder policies and permitted by publishers and copyright law.

The Leeds Beckett repository holds a wide range of publications, each of which has been checked for copyright and the relevant embargo period has been applied by the Research Services team.

We operate on a standard take-down policy. If you are the author or publisher of an output and you would like it removed from the repository, please contact us and we will investigate on a case-by-case basis.

Each thesis in the repository has been cleared where necessary by the author for third party copyright. If you would like a thesis to be removed from the repository or believe there is an issue with copyright, please contact us on openaccess@leedsbeckett.ac.uk and we will investigate on a case-by-case basis. 


\title{
The Emergence of Politics as a Taught Discipline at Universities in the UK
}

Author: Professor John Craig, Dean of Social Sciences, Leeds Beckett University

\begin{abstract}
While existing disciplinary histories of political science focus on areas such as the development of research agendas, establishment of chairs, and the founding of subject associations, little work has been undertaken on the history of teaching and learning. Based on extensive archival work and use of contemporaneous documents and surveys, it combines data sources, which have not previously been used in writing the history of political science. These are used to construct a history of the taught discipline which traces the development of courses and curricula within UK universities during the twentieth century. In doing so, it makes a significant contribution to the history of political science, challenging existing accounts and chronologies of the development of politics in UK universities, through a more comprehensive account of its diverse origins. Keywords: Political Science; Disciplinary History; Teaching and Learning
\end{abstract}

Funding declaration: None

Declaration of conflicting interests: None 
Acknowledgments: I would like to thank the librarians and archivists at the institutions mentioned in the paper, for their assistance in identifying and accessing materials. I would also like to thank the two anonymous reviewers for their comments and feedback.

\section{Introduction}

This paper explores the emergence of Politics as a taught discipline within UK higher education. While there has been a growing interest in the history of politics as an academic subject in recent decades, this has predominantly focused on the evolution of ideas and on institutional developments such as the founding of departments, publication of key texts and the appointment of professors. It has tended to be a history of 'great men' and 'great books'. By contrast, there has been relatively little research on the educational aspects of this development and there has been little written on the emergence of politics degrees. We know little of when they first appeared, what they constituted, who studied them and what they learnt.

The aim of this article is to close some of these gaps. It begins with a review of the existing literature on the history of the discipline in the UK, identifying key themes that have emerged from this scholarship and the gaps relating to the history of the taught

discipline. The article then provides a brief history of the development of political science teaching in UK universities. This is divided into two sections, the first covering a period from the nineteenth century through to 1950 , and the second focusing on the period from 1950 to 1970 . By this latter date, the discipline had become firmly established within UK undergraduate provision. The next section of the paper discusses some of the reasons for 
these patterns of expansion and debates on the content of the politics degree. The article then concludes with a summary.

\section{Politics and Disciplinary History}

In recent decades, a significant number of studies have explored the history of political science. Much of this work has focused on the development of the discipline in the United States (for example Ricci 1984; Baer et al 1991; Farr and Seidelman 1993;

Sigelman and Sanders 2006), but there has also been work on international developments (such as Coakley 2004), and comparative studies (Easton et al 1991; Easton et al 1995; Adcock et al 2007). Less has been written on the development of the discipline in the UK and as Adcock and Bevir (2005: 1) observed, it is "striking that so little work has been done in Britain on the history of political science in the last forty years". Johnson (1989) and Hayward (1991) both provide broad surveys, tracing its development from the political economy of the early nineteenth century, to its consolidation as a distinct academic discipline during the twentieth century. For Hayward (1991) this is a story of growing professionalisation, while Johnson (1989: 136) is more critical, arguing that the discipline has been "corrupted by the passing show" of contemporary events and "made esoteric by the pursuit of an inappropriate scientific model". Other accounts cover shorter periods. Collini et al (1983) and Stapleton (1994) focus on the emergence of the idea of political science within British intellectual life in the late nineteenth and early twentieth centuries. Kavanagh (2003) explores the development of the discipline in the inter-war 
period, while Kenny (2004: 569) focuses on the 1950s and 1960s, the period during which, he argues, it transitioned from being a "loosely constituted community into an institutionally accepted academic discipline".

Other studies explore aspects of this story. King (1977) and Wokler (2001), for example, focus on professorial appointments. There are also studies of politics within single universities. The development of politics at the University of Oxford is explored in Chester (1986) and Hood et al (2014). Both provide narratives which include issues of staffing, estates, funding, research and curriculum, set within wider intellectual and institutional developments. The same is true of accounts of the development of political studies at the University of Edinburgh (Raab 2012) and University of Warwick (Grant 2015), both of which were produced as part of anniversary celebrations. Likewise, the 25th anniversary of the founding of the Political Studies Association (PSA) was marked by a special edition of Political Studies in 1975, with papers on the development of the discipline in the UK. A history of the association, published to mark its 60th year (Grant 2010), also provides extensive coverage of key developments in the discipline. There are also surveys exploring the intellectual developments of different sub-fields (Hayward and Norton; 1986; Gamble 1990; Hayward et al 1999).

Together, the existing studies provide a rich account of many aspects of the historical development of the discipline. It is told largely through the establishment of departments and Chairs, the publication of books and journals, and the development of key ideas and research programmes. A number of key events feature prominently in the literature and 
form a skeleton history of the discipline in Great Britain. These include the establishment of the London School of Economics and Political Science (LSE) in 1895, the creation of a Chair in Political Theory and Institutions at the University of Oxford in 1912, and the establishment of an Honours School in Philosophy, Politics and Economics, also at Oxford, in 1920. Various appointments are highlighted such as those of Harold Laski as Professor in Political Science at the LSE in 1926 and W.J.M. Mackenzie as Professor in Government and Administration at the University of Manchester in 1948. The founding of the PSA in 1950 and its Political Studies journal in 1952 are widely held to be key points in the emergence of the discipline, as was the development of post-war research funding for the social sciences. Overall, there is a substantial historical record of the various people and institutions that constituted British political science in its formative years.

An area that is less well covered in these accounts is the teaching of politics. This tends to be covered in a more sporadic fashion, with occasional discussions of degree structures, curricula, numbers of students, and pedagogical techniques. In the case of the University of Oxford, existing studies do provide a reasonably good coverage of key developments. But this is the exception. There is no published work that attempts to provide a wider and more systematic study of the emergence of politics as a taught discipline in higher education during the twentieth century.

Take, for example, the question of when the first single honours degree in politics was taught. There can be debates about what might constitute a politics degree and how this 
might have changed over time, but a basic chronology is required as a starting point. The existing literature suggests that single honours politics degrees were first taught in the 1960s. This is explicitly stated by Grant $(2010,6)$ who refers approvingly to a private communication between himself and Tony Birch, in which Birch recalled that "there were no single honours politics degrees in Britain until the 1960s". This is consistent with Vout (1990, 163), who states that while "between 1948 and 1957, the study of politics was beginning to emerge, slowly, outside the 'Thames Valley' (London, Cambridge, Oxford)... there was no single honours course in politics". But neither Vout nor Grant propose a date or location for the establishment of the first single honours degree. Likewise, Heater (1969), Dearlove (1987), and Kenny (2004), while all examining aspects of the development of politics within universities in the period, provide no indication of where the first single honours was established. In summary, while there has been a growth in disciplinary history in the UK over the last few decades, there has been significantly less focus on developments relating to teaching and learning and it is this deficit that this article aims to address. ${ }^{1}$

\section{Method}

The writing of disciplinary histories is not without conceptual and empirical challenges. Collini et al (1983: 4) argue that disciplinary histories can impose the structures of later periods on the intellectual debates of former times, and there is the risk that such histories become instrumental, used to legitimise current practices and positions. These are valid 
concerns, which I have sought to address through a number of strategies. Firstly, in defining what constitutes 'politics' or 'political science', the research has relied on

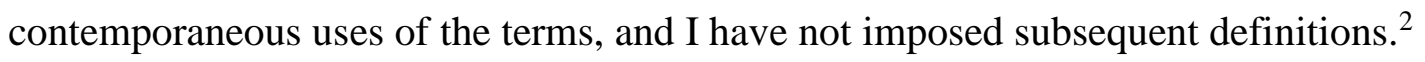

Secondly, the account presented identifies debates on the scope and nature of politics as a taught discipline, demonstrating that the course of development was contested and not inevitable. There is also an additional challenge, relating to the changing terminology used across the sector over time. For clarity, in the discussion below, I have used a standardised terms of 'degree' or 'award' to refer to the whole programme of study that has been designed, and 'course' to refer to a part of that (such as a 'module' or a 'paper'). The titles of awards and courses are in inverted commas for clarity.

The process of gathering data was conducted in two stages. During the first stage, a range of existing materials were consulted to construct a high-level national picture of when and where there was prima facie evidence of politics being taught. Three types of source were used to construct this: contemporaneous surveys of the discipline; official records and reports; and the existing histories, such as those noted earlier.

Among the contemporaneous surveys identified were Cole (1950) and Hanson (1952), which were part of a major international survey of political science undertaken by UNESCO. There are also a range of smaller scale surveys and overviews. These include a report by the American political scientist Farlie (1924) and a survey of politics teaching in the mid-1960s, undertaken by Nettl and Simpson (1966) following discussions at an informal conference on emerging issues in the discipline in 1964, and prepared for the 
Political Studies Association Annual Conference in 1966 (Jones and Alderman 1965; 392). Tansey (1981) and Berrington and Norris (1988) also provide later surveys of the provision of politics degrees at UK Universities. The reports and records of government and sector bodies are also drawn from a range of sources. From 1926, the University Grants Committee (UGC) collected and published data on the subjects in which honours degrees were awarded to students, and while both the Clapham (1946) and Heyworth (1965) Committee reports were primarily focused on the development of social science research, the latter also collected data relating to teaching provision and student numbers. Data on the development of degrees was also collated from the annual University Central Council on Admissions (UCCA) handbooks, which were published annually from 1962, and provided the fullest record of the awards that were offered by universities in this period.

Together with existing studies of the discipline, these materials provided a series of, sometimes contradictory, snapshots of the discipline and were the starting point for the next phase of the research. This second phase focused on accessing records relating to award structures, curriculum, and student outcomes. Where these exist, they are generally found in university calendars, prospectuses and other publications, held in the archives or special collections of individual institutions. In all, 21 university libraries and archives were visited, as well as the National Archive. ${ }^{3}$ Additional documents were accessed through the British Library and the Universities and Colleges Admissions Service (the successor organisation to UCCA). It should be acknowledged that the records held are not always complete and that they can tell only part of the story. To look at a syllabus is 
often to see the end of a process. The discussions, debates, logistical constraints and compromises that produced it are rarely recorded. Nevertheless, sufficient materials are available to shed significant light on the development of politics as a taught discipline.

\section{The developing discipline: a national picture}

This section provides a narrative of the development of politics teaching in British universities. It is divided into two parts. The first deals with developments before 1950 . This marks the year when the PSA was founded and proved to be a watershed for the discipline. The second part covers the 1950s and 1960s, during which the discipline developed a stronger sense of identity and further expanded. By the end of this period, politics degrees were firmly established within UK undergraduate education.

\section{Politics before 1950}

As Mackenzie (1967: 57) states "there has always been political science in the universities, since it is impossible to teach law, history, philosophy, theology, or indeed literature... without being drawn into discussions about the polity". In the United States, Haddow (1969) traces this back to colleges in the colonial period where normative questions relating to political rights and legitimacy were taught within ethics and moral philosophy. In the United Kingdom, Collini et al (1983) explored how the idea of a 'science of politics' emerged from the Scottish Enlightenment and became established within university curricula during the nineteenth century. Indeed, the first book published 
in English to use the term 'political science' in the title, Adam Fergusson's (1792)

Principles of Moral and Political Science, was based on his lectures to students at the University of Edinburgh.

These early developments should be placed within the context of intellectual and institutional life in this period. Firstly, although the term 'political science' was in use by 1800, it did not constitute a clearly defined and distinct academic field and until the second half of the nineteenth century, the subjects that now constitute the social sciences, generally fell within the scope of what was referred to as ethics, moral sciences and philosophy. As Johnson (1989: 15) has put it "politics was not viewed as a distinctive mode of action or even as a clearly defined structural feature of social life: it was continuous with moral conduct and social regulation". In this sense, as Collini et al (1983: 3) note, the political science that existed in nineteenth century universities was "only indirectly related to what the twentieth century" came to know by this name. The second contextual aspect relates to the development of universities. During the nineteenth century there were few universities in the UK, with teaching at Oxford and Cambridge dominated by classics and mathematics respectively. While there was growing social pressure for change, it was not until the end of the century that a greater variety of honours degrees became established, and a range of new institutions appeared, offering more alternatives for students.

The first usage of the term 'political science' within a degree title that I have been able to identify was at the University of Wales in the 1890s. The University of Wales was 
established in 1893, drawing together a number of pre-existing colleges. By the end of the century, both the University College of Aberystwyth (later the University of Aberystwyth) and the University College of South Wales and Monmouthshire (later the University of Cardiff) offered a degree in 'Political Science (including economics)'. At Aberystwyth, this was limited to an ordinary degree, first awarded to three students (Robert Jenkyn Owen, Alice Mary Smith, and Caroline Pearse Tremain) in 1898, while at Cardiff, it was offered at honours level and first awarded in 1903 to John Harry Jones (University of Wales 1898: 98; 1905: 196). These were the first students to be awarded a degree by a British university in which the term 'political science' was used. However, as the title of the award suggests, disciplinary boundaries were not clear cut. At Cardiff, students studied courses on 'Politics', which was primarily concerned with the state, and 'Political Theories', which focused on the development of political thought in England. In addition, they studied courses on economic history, and the history of political economy. The prescribed texts were Leviathan and The Wealth of Nations (University of Wales 1900 xxxi - xxxii). By the end of the decade, the curriculum shifted in the direction of economics and in 1910 the degree was renamed 'Economic and Political Science' (Baber 1983).

Politics also emerged in tandem with economics elsewhere in this period. At the LSE, it formed part of a broad based 'BSc (Econ)' which also included courses on economics, history, public administration, and methods of investigation. Students could choose from a range of identified special subjects at honours level, including 'Public Administration' and the 'History of Political Ideas' (LSE 1903: 51). ${ }^{4}$ Both were replaced by a special 
subject option in 'Government' from 1930 (LSE 1927: 203-6). At both the University of Manchester and University of Leeds, a 'BA (Hons) in Economics and Political Science' was established. As at the LSE, students were required to study a broad range of subjects as well as the two areas named in the award title. At Manchester (1915: 65), the 'Political Science' component was described as covering "the history of political thought and analytical politics", while at Leeds (1915: 228), students studied 'Political Theory', which covered "the nature and duties of the State and the basis of citizenship".

Politics advanced more slowly and unevenly in the curriculum of the older universities. At Cambridge, 'Political Science' formed part of the 'History' Tripos from the 1880s and political philosophy was taught within the Moral Sciences Tripos (Collini et al, 1983:

345-7). However, while an Economics Tripos was established in 1903, no politics degree was developed until the current century (Tribe 2000: Gamble 2009). At Edinburgh an honours level course on 'Political Science' was approved in 1900 for students studying for degrees in 'History' and 'Economic Science', but the term did not appear in any degree title (Raab 2012: 37-40). Likewise, at Glasgow (1900: addendum; 1901: 75-6), a course on 'Political Philosophy' was introduced for students studying for MA Honours in 'Mental Philosophy' or 'Economic Science' and at Aberdeen (1905: 144-5) a course on 'Political Science' was made a requirement for a degree in 'History', but again the term remained absent from any degree title.

At the University of Oxford things progressed differently. Here political science had become an established element of the syllabus for 'Literae Humaniores' (known as 
‘Greats'), 'Modern History', and ‘Jurisprudence' (Ritchie 1891). In 1912, Oxford established what is regarded as the first chair in the discipline at a British university, with the appointment of W.S. Adams as Professor of Political Theory and Institutions (Wokler 2001: 139). This was followed by the establishment of honours in 'Philosophy, Politics and Economics', popularly known as 'Modern Greats' or by its abbreviation of PPE, in 1920. The new degree required that students studied papers including 'Moral and Political Philosophy', 'British Political and Constitutional History from 1760', 'British Social and Economic History from 1760' and 'Political Economy' (University of Oxford 1922).

Table 1: Subjects in which honours degrees relating to Politics were awarded in UK universities

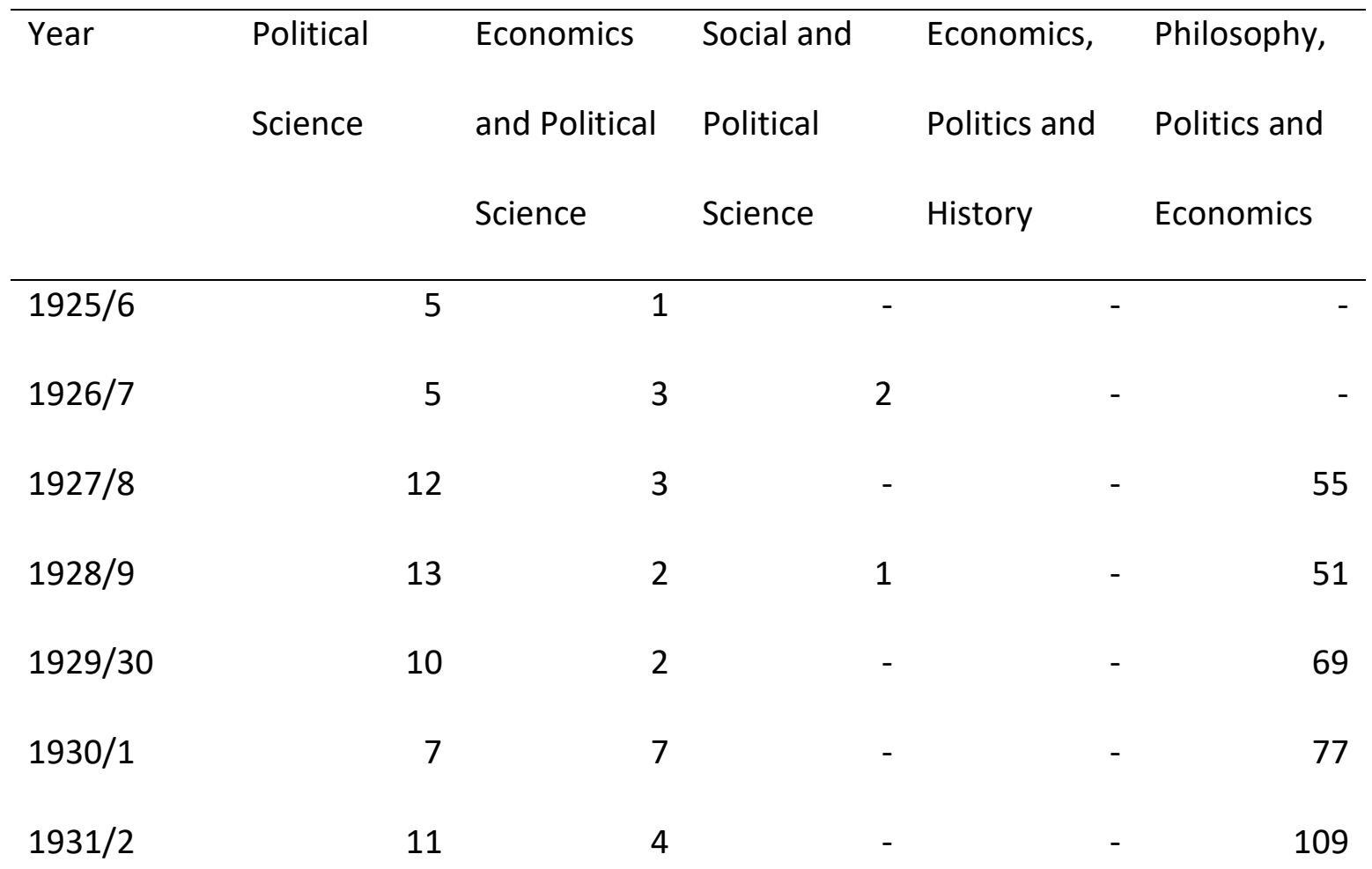




\begin{tabular}{lccccc}
$1932 / 3$ & 10 & 11 & - & - & 96 \\
$1933 / 4$ & 14 & 2 & 1 & 3 & 102 \\
$1934 / 5$ & 11 & - & 1 & 1 & 106 \\
$1935 / 6$ & 12 & - & 1 & 6 & 111 \\
$1936 / 7$ & 6 & - & - & 3 & 108 \\
$1937 / 8$ & 20 & - & - & 5 & 119 \\
$1938 / 39$ & 13 & - & - & 4 & 110 \\
\hline Source: UGC $(1926 ; 1927 ; 1928 ; 1929 ; 1930 ; 1931 ; 1932 ; 1933 ; 1934 ; 1935 ; 1936 ; 1937 ;$
\end{tabular}

$1938 ; 1939)$

As outlined in Table 1, during the inter-war period, PPE had a far higher through-put of students than other degrees classified by the UGC as including politics. The students classified as 'Political Science' during this period, were probably the graduates of the BSc (Econ) at the LSE whose Special Subject was 'Public Administration' or 'History of Political Ideas' and, after 1930, 'Government'. ${ }^{5}$ Farlie $(1924,575)$ judged that the LSE had become established as the centre of the "largest and most important work in political science in Great Britain”, offering "an imposing schedule of courses on various branches of political science". Harold Laski, who taught at the LSE at this time concurred, stating that outside the LSE, "there is little attempt at its organised teaching" beyond "a course of 
lectures on the government of England, and critical accounts, of widely varying quality and content, of the philosophy of the state" (Laski and Caudel 1925, 97).

But provision was also being developed at other universities in these years. At Oxford, changes to the structure of PPE in 1932 increased the politics content, with additional specialist papers added in 'Public Administration', 'International Relations', 'Political Structure of the British Empire' and 'Political Theory Since 1760' (Chester 1986: 43). In 1936, Manchester (1936: 82-4) introduced a 'Politics' route in the 'BA (Hons)

Economics and Politics' which allowed students to develop a greater focus on 'Political Philosophy' or 'Public Administration' at honours level. Liverpool also introduced a 'Political Science' specialism in their BA (Hons) Social Sciences in 1937, with students required to study 'Public Administration', 'International Relations', 'British Constitutional History', and 'Political Philosophy' (University of Liverpool 1937: 198-9). Elsewhere, politics was emerging as part of combined degrees. During the inter-war period, the University of Birmingham (1919; 168-174) offered a 'BA (Hons) Social and Political Science', while at Queen's University Belfast (1924: 188) students could study for a 'BA (Hons) Economics, Economic History and Political Science', and at St. Andrews (1939: 112-13) honours in 'Political Science' were awarded in combination with either 'Economics', 'History', 'Philosophy' or 'Moral Philosophy'. As such, although by the end of the 1930s there were no single subject honours degrees offered, Politics could be found within the curriculum of most British universities.

\section{Post 1950}


Surveying the post-war scene, Cole (1950: 617) stated "as far as I know, no British University offers a first degree in Politics alone". His account of politics in British universities is focused almost exclusively on Oxford, where he had been a student of 'Greats', taught 'Modern Greats' and, at the time that he wrote, held the Chichele Professorship of Social and Political Theory. For Cole (1950: 622), the creation of PPE was an "outstanding achievement in the study of Politics as an element in a wider synthesis relating to modern problems" and while there are passing references to developments in London, Birmingham, and Scotland, the picture presented is of a subject taught in few places. The approach contrast with that of Hanson (1952), which captures more of the breadth and diversity of provision in the sector at the time. Hanson, a Lecturer in Public Administration at the University of Leeds and later its first Professor of Politics, identified 18 institutions offering degrees "which include political science as a major part of their examination requirements" (Hanson 1952: 9). ${ }^{6}$ Among these were the University of Nottingham which he identified as the only place where "students can take a first degree described as one in 'Politics"' (Hanson 1952:1). ${ }^{7}$

Although a Department of Politics was not established at the University of Nottingham until 1965, a 'BA (Hons) Politics' degree was offered from 1950. This included courses in 'Political Institutions', 'Political Theory', 'British Constitutional History', 'Modern British Government' and 'Local Government', as well as a dissertation in the field of 'Public administration' (University of Nottingham 1950, 48). There were various adjustments to the curriculum in the years that followed, including the addition of a course in 'Comparative Politics' in 1954 (University of Nottingham 1954, 35-6). This 
was the first honours degree in the UK, which claimed to provide an education focused on the single discipline of politics. The first graduates (Joseph Ifeatu Emembolu and Frederick Wellesley Jones) were awarded their degrees in 1952, with a further 69 graduates following them by the end of 1964 (University of Nottingham 1958; 1959; 1964). By this time, according to Tolley (2001: 134), it had become a department where "good teaching and pastoral care were emphasised".

By the time the first UCCA handbook was published (UCCA 1962), Nottingham's lead had been followed by other universities. In 1952, Exeter and Leicester were University Colleges which Hanson listed as preparing students for the London 'BSc (Econ)' and both gained University status later in that decade. From 1956/57 the University of Exeter (1956: 258-62) offered a 'Government' special subject route in their BA (Hons) Social Sciences, and Leicester (1958: 183-7) offered 'Politics' as a 'Main Subject' in their 'BA Special degree in Social Sciences' from 1958/9. As noted above, both Liverpool and Leeds had taught politics within combined degrees earlier in the century. From 1960 Leeds (1960: 35) offered the option of 'Special Studies in Political Studies' within the 'BA Social Studies' degree, while from 1958/59 'Political Theory and Institutions' was offered within the 'BA (Hons) in Special Studies' at Liverpool (1958: 213). Finally, within the University of Wales, the University College of Swansea (1961: 122-3) (now University of Swansea), offered honours degrees in 'Politics' from 1961/62, also having previously offered joint-honours options. The case of Aberystwyth was rather different. Here a 'BA (Hons) International Politics' was offered from 1961/2, but this was 
essentially an international relations degree and a separate 'Political Science' degree was added in the mid-1960s (University College of Wales Aberystwyth 1961: 23-4).

As identified in Table 2, there was a steady stream of new single honors politics degrees offered through UCCA during the 1960s, and by the end of the decade, about a third of universities were offering a single honours degree in politics. ${ }^{8}$ In addition, a further third were offering the subject in either joint degrees or as an identified route within a wider BA or BSc (Econ). It was also not unusual for institutions to change the way in which these were offered to applicants. Aberystwyth, Birmingham, Essex and Leicester all made several changes to the presentation of politics options in UCCA between 1963 and 1969, and Nettl and Simpson (1966: 1), noted that similar awards could be identified "as combined honours [at some universities], while others treated them as special Honours degrees".

Table 2: Single or special honours politics courses entering UCCA listings.

\begin{tabular}{lll}
\hline Year & Institution & Award \\
of & & \\
Entry & & \\
\hline 1963 & University College of & BA (Hons) International Politics \\
& Wales, Aberystwyth & \\
& University of Exeter & BA (Hons) in Social Science. Government \\
& University of Leeds & BA in Special Studies. Political Studies
\end{tabular}


University of Leicester

University of Liverpool

University of Nottingham

University College of

Swansea

1964

University of Strathclyde ${ }^{a}$

1965

University of Edinburgh

University of Kent at

Canterbury.

University of Lancaster

University of Sheffield
BA Special Honours in the Social Sciences. Politics

BA in Special Studies. Political Theory and

Institutions

BA with Honours (Social Science). Politics

BA Honours. Politics

BA Political Theory and Institutions

MA Honours. Politics.

BA Honours (Social Sciences) Politics

BA with Honours Politics.

BA (Econ) Special Honours. Political Theory and Institutions.

MA Honours Political Studies

University of Essex

BA Hons Government

University of Sussex

BA International Politics.

University of York

BA Politics

1967 University of Reading

BA Politics

University of Dundee

Honours degree of MA Political Science 
University of

Southampton

1968 University of Warwick

1969 University of Birmingham
BSc (Social Science) Politics and International

Studies

BA (Hons) Politics

B Soc Sci Honours Political Science

Source: UCCA (1962;1963; 1964; 1965; 1966; 1967; 1968; 1969)

Notes: The table is cumulative. Awards only included if listed for two consecutive years

or more. Subsequent changes in award titles are not included.

[a] Initially listed as Royal College of Science and Technology.

In part, this reflected on-going questions relating to specialization and the extent to which politics was a suitable subject for a single honours degree. At the start of the 1950s, Hanson (1952:1) had noted:

There is an almost universal opinion that the political subjects, without the support from others, e.g. history, economics, philosophy, sociology or anthropology, cannot provide the undergraduate with a sufficiently wide and balanced course of study. 
Despite the growth of single honours provision, such views remained influential during the following decades. For example, Chapman (1970: 73-4) noted that the Department of Government at Manchester had continued to support a "Faculty policy of resisting the introduction of single honours", taking the view that undergraduate students should become familiar with a range of disciplines before specialising. At Sheffield, Crick (1970: 34) expressed his "continual and open scepticism about the value of single Honours Politics (perhaps Single Honours anything) compared to the value of Dual schools", having explained in the university prospectus that:

The student taking the Single Subject School of Politics will inevitably gain little knowledge of the main concepts of History, Sociology, Philosophy, Economics and Economic History. But a Dual Subject course with one of these subjects will give most students a better general education and a better preparation for secondary or adult teaching, government service or journalism (University of Sheffield 1968, np).

Such views on the dangers of over specialisation were shared in the sector and resulted in various moves to offer more breadth at both old and new universities. While a single honours politics degree continued to be offered, Sheffield moved to offer more opportunities for students to study a range of social sciences and pursue dual or triple honours. At York, students taking a BA (Hons) Politics initially studied a common social sciences curriculum before confirming their single or combined honours choice. As the 
Prospectus outlined, this ensured that "no student embarks on specialised studies within the social sciences unaware of the relationship between his chosen field and the others" and could explore their "aptitude and interests" before committing to a particular field (University of York 1970: 78).

These patterns of provision established in the university sector by the end of the 1960s were to remain relatively unchanged for the next twenty years. When Berrington and Norris (1988: 16) surveyed the scene, they reported "36 universities which offer single subject politics, international relations and public administration degrees in the UK", and while Tansey (1981: 14) had noted that single honours degree were "dominating the thinking of universities and many university-trained graduates in politics", they still accounted for "only a small part of Politics curricula in higher education". This reflected not only the ongoing popularity of joint and combined degrees in the university sector, but also the growth of provision in the polytechnics and other colleges offering higher education. Bristow and Randall (1981: 24-6) identified 37 such institutions offering degrees which included politics. These included 12 "single subject politics degrees", although reflecting the more applied focus of these institutions, more than half were degrees in 'Public Administration'. After 1992, the polytechnics were incorporated into the university sector and much of this public administration teaching would disappear, and single honours politics degrees modelled on those found in the older universities were offered.

\section{Explaining the Emergence of the Taught Discipline}


The account provided above maps the growth of politics teaching in universities and has focused on the emergence of single honours politics degrees. This section begins by addressing the question of why the taught discipline emerged at this time, before turning to explore developments in their content and scope.

Four factors can be identified as particularly relevant to the emergence of politics as a taught discipline. The first is the significant expansion of higher education in this period. At the start of the twentieth century there were just ten universities in the current territory of the UK (Tight 2009: 52). By 1948 the number had grown to eighteen and by the end of the 1960s to forty-seven. Although over time they would seek to emulate older universities, the newer universities were often established as innovator institutions, aiming to offer different subjects and advance educational opportunities (Barnes 1996). This was accompanied by an increase in the number of students attending university. Full-time undergraduate numbers increased from under forty thousand in 1945, to over ninety thousand by 1960 and to more than a hundred and eighty-six thousand by 1970 (Tight 2009: 55). Taken together, the rise in the number of students and institutions produced a favourable context for the development of new disciplines.

The second contextual factor was the development of the social sciences. As outlined in an earlier section, economics and politics had entered the university curriculum in the later nineteenth century. However, these subjects were generally subsumed within faculties of arts or seen as an aspect of commercial education. As King (1997) argues, 
this began to change due to wartime experiences of planning and the post-war commitment to an expanded welfare state. The Clapham Committee (1946) had recommended expanding support for the provision of social sciences in the universities and during the following decade the UGC provided increased funding and moved to recognise the social sciences as a distinct set of disciplines. Their status was further enhanced by the Heywood Committee (1965) which established the Social Sciences Research Council (later renamed the Economic and Social Research Council). In addition, post-war social science provision was developing in secondary education, with the introduction of A-level qualifications in areas such as economics, politics, and sociology (Stewart 1989: 150-1).

While these developments provided a fertile environment for the development of politics as a discipline, it was not a foregone conclusion that this would emerge as a standalone area of undergraduate study. We have noted the views of leading figures such as Hanson and Crick, who were sceptical of the value of single subject politics degrees. Likewise, shortly after taking up the chair in Political Theory and Institutions at the University of Liverpool, Wilfred Harrison (1957: 221) thought it unlikely that "political studies will succeed in many British universities in forming the centre in an honours school around which other subjects will be grouped".

This brings us to student behaviour as the third explanatory factor. As Mandler (2015) argues, this was a key driver within universities during the twentieth century due to the demand led nature of the British higher education system. As Thompson (1969: 65) 
noted, secondary school students were often "fascinated by political controversies like civil rights in Northern Ireland, Vietnam, 'student power' or immigration”. To increasing numbers, studying a social science at university appeared an attractive choice "not only because it seemed exciting and 'relevant' but also because it seemed good preparation for careers in local government, social work, commerce and management” (Mandler 2015: 412). This latter point was often highlighted to applicants by universities in their publications. For example, as the University of Exeter (1966: 405), explained degrees in government could "provide an excellent background for those whose careers may be in central or local administration at home or overseas, or in politics, as well as in some branches of teaching”. Indeed, an analysis of UGC data by Lovenduski (1981: 14) demonstrated that between 1966 and 1975 the most common destination for politics graduates were industry and commerce, local government, hospitals and the civil service.

The fourth factor was the behaviour of universities, and they responded in different ways to this growth in student demand. It is noticeable that those with the most successful joint or combined politics provision and the strongest research profiles (Oxford, LSE, and Manchester) chose not to establish single honours in the subject. Instead, this was led either by institutions that had recently gained university status (such as Nottingham, Exeter and Leicester) or those that had long-standing joint honours provision but were seeking to expand (such as Liverpool and Leeds). In many ways, this echoed the experience at the start of the twentieth century, when developments in joint and combined politics degrees where led by the new English civic universities and Welsh university colleges, rather than the ancient universities. In both cases, it is likely that institutions 
with well-established provision had both less incentives to innovate, as well as more interest in maintaining existing structures.

We now turn to consider the changing scope of the politics curriculum during the postwar expansion. The rapid growth in provision gave rise to concern that there was a lack of consistency between degrees variously described as 'Politics', 'Political Studies', 'Political Theory and Institutions' and 'Government' (Crick 1966; 631), although Wiseman (1967: 1) judged that all these were "virtually synonymous". For Nettl and Simpson (1966: 3) the "equivalence of different courses" was the "most urgent question" for the discipline, but they found a considerable degree of commonality, with 'Modern Foreign Government', 'Social and Political Philosophy' and 'British Government' as the most commonly required courses, a pattern that was most pronounced among degrees identified as single honours.

However, beneath this apparent consensus, there were on-going processes of change and debate. This has often been characterised as a conflict between an older approach to political studies, based firmly in the traditions of philosophy and history, and a modern approach to the subject, conceptualised more explicitly as a social science and influenced by intellectual currents such as behavioralism (Dearlove 1987; Johnson 1989; Vout 1990; Hayward 1991; Kenny 2004). This was certainly one aspect of the debates within the discipline during this period. Jones and Alderman (1965: 392) noted the "widespread dissatisfaction" expressed at the informal conference in 1964, with what was characterised as an insufficiently conceptual and analytical approach to the subject. For 
Preece (1969: 472) conflicts within departments between traditionalists and modernists risked having an adverse influence on teaching, while for Chapman (1970: 73), "the main teaching problem" was "how to marry the traditional disciplines of political theory, law and philosophy with the newer branches of study".

While Dearlove (1987: 129) argues that a relatively uncritical approach to the British political system, focusing "on formal political structures and not political behaviour", remained in place throughout the 1960s, for Dowse (1967: 126) the taught discipline changed significantly with "a veritable revolution" taking place in the courses offered to students. An inspection of university calendars and prospectuses during this period, demonstrates a widespread process of change, but variation between institutions. Both Essex and Strathclyde, which were recognized as departments that embraced behaviouralism more fully than others, emphasized the methodological focus of their politics degrees. Essex (1964: 13) stated that "students will engage in practical work involving the use of interviewing techniques and statistical methods" and highlighted the opportunities to undertake advanced courses in mathematics as part of the degree, while Strathclyde (1969: 51), outlined to applicants, that their politics degree provided "an unusual opportunity to acquire general Social Science skills, including expertise in survey work and in the use of computers, as well as a liberal education in evaluating problems involving a mixture of values and empirical data". In other cases, courses were offered which introduced students to the more recent theoretical approaches. At Edinburgh (1964: 465) and Sussex (1964: 58), students were required to study courses on political sociology, which explored issues such as "social groups and political behaviour", 
"pressure groups and parties" and "opinion and its measurement". In the case of Edinburgh, a list of recommended readings was included, which was dominated by key American behaviouralist texts. At Liverpool (1964: 75) optional courses were offered on 'Political Parties and Pressure groups' and 'Elections and Representation', while Nettl and Simpson (1966: 4) noted the use of courses on 'Political Science' at some institutions to achieve the same end. The general pattern was one of an accommodation through an expansion of the curriculum.

In part, these diverse patterns of change reflected the relatively eclectic character of the discipline in Britain during this period. Crick (1966: 682) estimated that, almost two thirds of those teaching politics had completed a BSc (Econ) or History degree, while about a sixth had taken PPE. While these experiences no doubt influenced their approach to the subject, those writing about their intellectual development during this period, typically refer to a multiplicity of influences (see for example Barry 1980, Finer 1980 and Miller 1980). In addition, Goldsmith and Grant (2007: 382) observe, that while Chester, Mackenzie and Harrison were dominant figures in the post-war discipline, each was "more interested in stimulating students and colleagues into opening up new areas of work and trying out new ideas" than imposing a single approach. As such, the trends towards greater professionalization, did not necessarily impose greater conformity.

Bevir and Rhodes (2007) have also challenged the focus on a binary opposition of modernist versus traditionalist approaches. They highlight both the extent to which newer approaches were absorbed and co-opted into on-going debates, and the continuing role of 
other traditions, such as socialism and idealism, within British political studies. Such processes can also be identified in the debates around the curriculum. The concern that the institutional side of the subject could be untheoretical and overly descriptive was not entirely new and could be found in the older political studies tradition. Cole (1950:629) had argued that if the philosophical aspect was neglected, students studying institutions could "achieve examination success by the sheer accumulation of information and by commonsense collation of it, without the need to show much grasp of theoretical issues". Likewise, when Miliband (1975) criticized approaches to the teaching of political science which focused on political systems without reference to underlying structures of social and economic power, this was directed at both the traditional political studies curriculum and the positivist neutrality of behavioural approaches. ${ }^{9}$

In addition, debates around behaviouralism were not the only factors influencing change in the curriculum during this period. For example, the introduction of courses on the politics of European integration (Nottingham 1965: 42; and Aberystwyth 1968: 99) and the politics of developing areas (Leeds 1968: 88; and York 1969: 82-3), reflected contemporary political issues. These broadened not just the geographic scope of the discipline, but also widened the range of theoretical approaches and the issues that were discussed. Nevertheless, the core identified by Nettl and Simpson (1966) was to remain in place, and at the start of the 1980s Tansey (1981: 15) could still refer to "a 'Holy Trinity' of British Politics, Political Theory or Philosophy, and Comparative Politics (based on the UK, USSR, France and USA)" as central to most degrees in politics. 


\section{Conclusion}

This article provides a history of the development of politics as a taught discipline in UK universities. In doing so, it explores an aspect of disciplinary history that has received little attention in the existing literature. It is based on research that has accessed and synthesised multiple data sources, which have not previously been brought together. As a result, it provides a more systematic account that captures developments at a wider and more diverse range of institutions than previously explored. In contrast to the existing literature, it highlights the wide extent of politics teaching within the sector in the first half of the twentieth century and places the date for the emergence of the first single honours politics degrees in the 1950s, rather than the 1960s. It demonstrates that by the end of the 1960s, single honours politics degrees were an established element of the higher education landscape with a common core curriculum.

However, this picture is far from being a story of the triumph of single honours politics. As Adcock, Bevir and Stimpson (2007: 3) have argued, disciplinary histories should "unpack the contingent origins of dominant traditions, recover alternative traditions... or question the naturalizing histories by which practitioners of a discipline legitimate their own approaches", and what is apparent in this study is the extent to which the emergence of politics as an independent area of education was not expected and then resisted by some leaders in the profession.. Indeed, during the period in which single honours politics degrees became established and widespread, they were part of a wider eco-system in which politics contributed to a range of combined and joint degrees. As such, the article 
highlights the value of research on the development of the taught discipline as an essential, if hitherto under researched, element of political science disciplinary history and opens the way for further research in this area.

\section{Notes}

1. Some material has been published on the development of other social sciences as taught disciplines. Fincham (1975) provides a detailed account of the emergence of sociology degrees in England, while Kadish and Tribe (1993) cover aspects of the development of economics education. Haddow (1969) provides a history of the development of politics degrees in the United States from the seventeenth century to the end of the nineteenth century.

2. The terms 'politics' and 'political science' have been used interchangeably for much of the period discussed. The term 'Government' has also been used for departments and award titles, but as demonstrated in the UGC returns discussed below, this could also be interchangeably.

3. Aberystwyth; Bradford; Bristol; Cardiff; Edinburgh; Exeter; Glasgow; Keele; Leeds;

London; London School of Economics; Liverpool; Manchester; Newcastle; Nottingham; Oxford; Queens Belfast; Sheffield; Strathclyde; St. Andrews; York. 
4. The first graduate of the 'BSc (Econ) special subject Public Administration' was first awarded to George Thomas Reid in 1906, while the 'BSc (Econ) special subject History of Political Ideas' was first awarded to Edwin Evelyn Housley in 1914 (LSE 1934: 89 and 158)

5. UGC reports do not identify which honours degrees were awarded at which universities. However, the number of graduates from these specialist routes reported by the LSE for each year between 1926 and 1938, match those reported in the UGC reports for each year (LSE 1925-6 - 1939-40)

6. For context, at this time there were only 18 universities in the UK. Hanson's list includes a number of institutions that did not hold university status at that time. The only universities that Hanson does not identify as having significant politics teaching are: Cambridge; Edinburgh; Manchester; Liverpool; Belfast; and Reading.

7. The University of Glasgow is listed by Hanson as offering an 'MA (Hons) in Politics', which in the context of Scottish Universities is an undergraduate degree. Inspection of university calendars for the period show that Politics first appeared as a distinct area for study as honours level in 1949, but students were required to study this in combination with either 'Moral Philosophy’ or 'Political Economy' (University of Glasgow 1950). As such it was not a single honours degree. 
8. The 12 institutions listed in Table 2 as recruiting students to start degrees in 1965 , is more than the 7 identified by Nettl and Simpson (1966: 3). The difference is accounted for by gaps in the Nettl and Simpson data set. Aberystwyth is listed as not responding to the survey, while Kent and Lancaster were among a group of universities not sent a questionnaire as they were not expected to establish provision so quickly. Nottingham and Strathclyde appear to have returned questionnaires but were not included in the table of degree structures by Nettle and Simpson. No reason is given for this. There are no cases in which I have identified a university as offering single honours politics, if they were classified otherwise by Nettl and Simpson.

9. Indeed, an on-going debate would be pursued for some decades about whether British politics textbooks had sufficient theoretical content (see Epstein 1987; Robins 1996; Smith 1999; Jones and Robins 2000).

\section{Bibliography}

Adcock R and Bevir M (2005) The history of political science. Political Studies Review 3 (1): $1-16$

Adcock R, Bevir M and Stimson SC (eds) (2007) Modern Political Science: AngloAmerican exchanges since 1880. Princeton: Princeton University Press 
Adcock R, Bevir M and Stimson SC (2007) A History of Political Science: How? What? Why?. In: Adcock R, Bevir M and Stimson SC (eds) Modern Political Science: AngloAmerican exchanges since 1880. Princeton: Princeton University Press

Baer, M, Jewell, E and Sigelman, L (eds) (1991) Political Science in America: Oral Histories of a Discipline. Kentucky: University Press of Kentucky 1991

Baber C (1983) Economics. In: Crimes SB (ed.) University College Cardiff: a century history. Cardiff: University College Cardiff pp.295-98

Barnes SV (1996) Civic Universities and the Triumph of the Oxbridge ideal. History of Education Quarterly 36 (4): 271-305

Barry B (1980) The Strange Death of Political Philosophy. Government and Opposition, 15 (3/4): $276-88$

Berrington, H and Norris, P (1988) Political Studies in the Eighties. Political Studies Association.

Bevir M and Rhodes RAW (2007) Traditions of Political Science in Contemporary Britain. In: Adcock R, Bevir M and Stimson SC (eds) (2007) Modern Political Science: Anglo-American exchanges since 1880. Princeton: Princeton University Press 
Bristow S and Randall V (1981) Politics in the Polytechnics. London: Political Studies Association and Centre for the Study of Public Policy, University of Strathclyde.

Chapman, B (1970) Government. In: Knapp J, Swanton M J, and Jevons, FR (eds) University perspectives. Manchester: Manchester University Press. pp 63-74

Chester DN (1986). Economics, politics and social studies in Oxford, 1900-85. Basingstoke, Hampshire: Macmillan.

Clapham Committee (1946) Report of the Committee of the Provision for Social and Economic Research. London: HMSO.

Coakley, J (2004), The organisational evolution of political science: the international dimension. International Social Science Journal, 56:179, 171-184

Cole, GDH (1950) The study of politics in British universities. In UNESCO Contemporary Political Science: A Survey of Methods, Research and Teaching. Paris: UNESCO pp 617-646

Collini S, Winch D and Burrow J (1983) That noble science of politics: A study of nineteenth century intellectual history. Cambridge: Cambridge University Press.

Crick B (1966) The Tendencies of Political Studies. New Society, 3rd November 1966; 681-683 
Crick, B (1970) Department of Political Theory and Institutions. The University of Sheffield Gazette, 50: 32-5

Dearlove J (1987) Developments in the study of politics at the undergraduate level. In: C. Harber (eds) Political Education in Britain. London: The Falmer Press, pp.125-146.

Dowse RE (1967) Political Behaviour: Parties, Groups and Elections In: Wiseman HV (eds) Political Science: An outline for the intending student of Government, Politics and Political Science. London: Routledge and Kegan Paul, pp. 1-28.

Epstein L (1987) Review article: books for teaching British Politics. British Journal of Political Science 17(1): 93-107

Easton D, Graziano L and Gunnell, J (eds) (1991) The Development of Political Science: A Comparative Survey London: Routledge

Easton D, Gunnel JG and Stein MB (eds) (1995) Regime and Discipline. Democracy and the development of political science. Ann Arbor: University of Michigan Press

Farlie J (1924) Political Science in Great Britain. American Political Science Review 18(3): 574-82.

Farr J and Seidelman R (eds) (1993) Discipline and History: Political science in the United States. Ann Arbor: The University of Michigan Press 
Ferguson, A (1792) Principles of Moral and Political Science. Edinburgh: A. Strahan and T. Caddel.

Fincham J (1975) The Development of Sociology First Degree Courses at English Universities, 1907-1972. PhD Thesis, London: City University

Finer SE (1980) Political Science: An Idiosyncratic Retrospective. Government and Opposition, 15 (3/4): 346-63

Gamble A (1990) Theories of British Politics Political Studies 38(3): 404-420

Gamble A (2009) The limits of politics: an inaugural lecture given in the University of Cambridge, 23 April 2008. Cambridge: Cambridge University Press.

Goldsmith M and Grant W (2007) British Political Science in the New Millennium. In: Klingemann H-D (eds) The State if Political Science in Western Europe. Opladen and Farmington Hills: Barbara Budrich Publishers, pp.381-398

Grant W (2010) The development of a Discipline. The history of the Political Studies Association. London: Wiley-Blackwell. 
Grant W (2015) The founding of a politics department. Politics at the University of Warwick. Warwick: PAIS, University of Warwick.

Haddow A (1969) Political Science in American Colleges and Universities 1636-1900. New York: Octagon

Hanson AH (1952) The Teaching of Political Science in Great Britain. A paper supplementary to the Main report. United Nations Educational, Scientific and Cultural Organisation. WS/022.77, Paris, 5 March 1952. LSE Archive. R (Coll) Misc 347 National Reports A-I

Harrison W (1957) The present state of political studies in Britain. Australian Journal of Politics and History 2(2): 218-225.

Hayward J (1991) 'Political science in Britain', European Journal of Political Research, 20(3-4), 301-322

Hayward J, Barry B, and Brown A (eds) (1999) The British Study of Politics in the Twentieth Century. Oxford: Oxford University Press

Hayward J and Norton P (eds) (1986) The Political Science of British Politics. Brighton: Wheatsheaf Books 
Heater, DB (1969) Politics as a university discipline and political education in schools Political Quarterly 40(3): 323-328

Heyworth Committee (1965) Department of Education and Science. Report of the Committee on Social Studies. London: HMSO

Hood C Desmond K and Gillian P (eds) (2014) Forging a discipline: a critical assessment of Oxford's development of the study of politics and international relations in comparative perspective. Oxford: Oxford University Press.

Jones, R and Alderman, R (1965) 'Politics: some problems of the discipline', Political Studies 13(3): 392-395

Johnson, N (1989) The limits of political science. Oxford: Clarendon Press.

Jones B and Robin, L (2000) 'For the guidance of Martians: a reply to martin smith on British politics textbooks' Politics: 20 (2): 105-109

Kadish A and Tribe K (eds) (1993) The Market for Political Economy: The Advent of Economics in British University Culture, 1850-1905 London: Routledge

Kavanagh D (2003) British political science in the inter-war years: the emergence of the founding fathers. British Journal of Politics and International Relations 5(4): 594-613 
Kenny M (2004) The case for disciplinary history: Political studies in the 1950s and 1960s. British Journal of Politics and International Relations 6(4): 565-583.

King D (1997) Creating a funding regime for social research in Britain: The Heyworth Committee on Social Studies and the founding of the Social Science Research Council. Minerva 35(1): 1-16

King P (1977) Introduction. In: King P (eds) The Study of Politics: a collection of inaugural lectures. London Frank Cass. pp ix-xiv

Laski H and Caudel (1925) 'Political Science in Britain and France' American Political Science Review 19(1): 96-103.

Lovenduski J (1981) The Profession of Political Science in Britain. Glasgow: Centre for the Study of Public Policy, University of Strathclyde, Studies in Public Policy, number 84

LSE (1903) The London School of Economic and Political Science Calendar 1903-4. London: LSE

LSE (1925-6 - 1939-40) University Grants Committee Annual Returns. LSE Archives. LSE/Central Filing Registry/III/D-H, Box 218 and 219.

LSE Calendar (1927) Calendar for the Thirty-Third Session 1927-8. London: LSE

LSE (1934) Register 1895-1932. London: LSE 
Mackenzie WJM (1967) Politics and Social Science. Harmondsworth: Penguin

Mandler P (2015) Ben Pimlott Memorial Lecture 2014: The Two Cultures Revisited: The Humanities in British Universities Since 1945. Twentieth Century British History, 26 (3): $400-423$

Miliband, R (1975) Teaching Politics in an Age of Crisis. The University of Leeds Review 18: $129-45$

Miller JDB (1980) A Tracery of Influences. Government and Opposition 15 (3/4): 446456

Nettl JP with Simpson J (1966) Political studies in universities in Great Britain. Paper presented to the Political Studies Association Annual Conference, 1966. LSE Archive. PSA, Box 22, File 1/1966

Preece RJC (1969) Teaching and examining Politics. Higher Education Quarterly 23 (4):472-76

Queen's University of Belfast (1924) Calendar for 1924-25. Belfast: Mayne Boyd and Son Ltd. 
Raab CD (2012) Fifty years and more: The Department of Politics at the University of Edinburgh. Available at:

http://www.pol.ed.ac.uk/_data/assets/pdf_file/0008/91466/Politics_Dept_History.pdf (accessed 14 November 2012).

Ricci DM (1984) The Tragedy of Political Science: Politics, scholarship, and democracy. (New Haven: Yale University Press).

Ritchie DG (1891) The Teaching of Political Science at Oxford Annals of the American Academy of Political and Social Science 2 (1): 85-95

Robin L (1996) Politics Education: Same ends, but new means. Parliamentary Affairs 49(3): 495-507

Sigelman L (eds) (2006) The American Political Science Review Thematic Issue on the Evolution of Political Science in Recognition of the Centennial of the Review. 100 (4)

Smith M (1999) Institutionalising the 'eternal return': textbooks and the study of British politics, British Journal of Politics and International Relations 1(1): 106-118

Stapleton J (1994) Englishness and the Study of Politics: The Social and Political Thought of Ernest Barker. Cambridge: Cambridge University Press.

Stewart WAC (1989) Higher Education in Postwar Britain. Basingstoke: Macmillan 
Tansey S (1981) 'Politics Courses in Higher Education: An Overview' Teaching Politics 10 (1): $13-26$

Thompson C (1969) Teaching Political Studies in the Secondary School - Values and Problems. Education and Social Science 1 (2): 65-71

Tight M (2009) The Development of Higher Education in the United Kingdom 1945. Maidenhead: Society for Research into Higher Education and Open University Press

Tolley BH (2001) The History of the University of Nottingham. Volume 2 Nottingham: Nottingham University Press

Tribe, K (2000) The Cambridge Economics Tripos 1903-55 and the Training of Economists The Manchester School 68(2) 222-248

UCCA (1962) How to apply for admission to a University. UCCA: London.

UCCA (1963) How to apply for admission to a University. UCCA: London.

UCCA (1964) How to apply for admission to a University. UCCA: London.

UCCA (1965) How to apply for admission to a University. UCCA: London. 
UCCA (1966) How to apply for admission to a University. UCCA: London.

UCCA (1967) How to apply for admission to a University. UCCA: London.

UCCA (1968) How to apply for admission to a University. UCCA: London.

UCCA (1969) How to apply for admission to a University. UCCA: London.

University College of Wales Aberystwyth (1961) Prospectus 1961-2. Aberystwyth:

University College of Wales Aberystwyth.

University College of Wales Aberystwyth (1968) General Prospectus 1969-70 1970-71.

Aberystwyth: University College of Wales Aberystwyth

UGC (1926) University Grants Committee Returns from the Universities and University Colleges in Receipt of Treasury Grant. London: HMSO

UGC (1927) University Grants Committee Returns from the Universities and University Colleges in Receipt of Treasury Grant. London: HMSO

UGC (1928) University Grants Committee Returns from the Universities and University Colleges in Receipt of Treasury Grant. London: HMSO 
UGC (1929) University Grants Committee Returns from the Universities and University Colleges in Receipt of Treasury Grant. London: HMSO

UGC (1930) University Grants Committee Returns from the Universities and University Colleges in Receipt of Treasury Grant. London: HMSO

UGC (1931) University Grants Committee Returns from the Universities and University Colleges in Receipt of Treasury Grant. London: HMSO

UGC (1932) University Grants Committee Returns from the Universities and University Colleges in Receipt of Treasury Grant. London: HMSO

UGC (1933) University Grants Committee Returns from the Universities and University Colleges in Receipt of Treasury Grant. London: HMSO

UGC (1934) University Grants Committee Returns from the Universities and University Colleges in Receipt of Treasury Grant. London: HMSO

UGC (1935) University Grants Committee Returns from the Universities and University Colleges in Receipt of Treasury Grant. London: HMSO 
UGC (1936) University Grants Committee Returns from the Universities and University Colleges in Receipt of Treasury Grant. London: HMSO

UGC (1937) University Grants Committee Returns from the Universities and University Colleges in Receipt of Treasury Grant. London: HMSO

UGC (1938) University Grants Committee Returns from the Universities and University Colleges in Receipt of Treasury Grant. London: HMSO

UGC (1939) University Grants Committee Returns from the Universities and University Colleges in Receipt of Treasury Grant. London: HMSO

UGC (1940) University Grants Committee Returns from the Universities and University Colleges in Receipt of Treasury Grant. London: HMSO

University of Aberdeen (1905) University calendar 1905-1906. Aberdeen: The Aberdeen University Press

University of Birmingham (1919) Calendar for the Session 1919-1920. Birmingham: University of Birmingham

University of Edinburgh (1964) Edinburgh University Calendar 1964-1965, Edinburgh; James Thin 
University of Essex (1964) University of Essex Prospectus 1964-5. Colchester: University of Essex

University of Exeter (1956) Calendar 1956-57. Exeter: University of Exeter

University of Exeter (1966) Calendar 1966-67 Exeter: University of Exeter

University of Glasgow (1900) The Glasgow University Calendar for the Year 1900-1. Glasgow: James Maclehose and Sons.

University of Glasgow (1901) The Glasgow University Calendar for the Year 1901-2. Glasgow: James Maclehose and Sons.

University of Glasgow (1950) University of Glasgow Calendar 1950/51 Glasgow: University of Glasgow

University of Leeds (1915) Calendar 1915-16. Leeds: University of Leeds.

University of Leeds (1960) The Faculty of Economic and Social Studies Prospectus. Leeds: University of Leeds. 
University of Leeds (1968) The Faculty of Economic and Social Studies Prospectus.

Leeds: University of Leeds

University of Leicester (1958) Calendar 1958. Leicester: University of Leicester

University of Liverpool (1958) The Calendar of Liverpool University 1958-59, Liverpool. Liverpool University Press.

University of Liverpool (1964) The University of Liverpool Calendar Session 1964-65. Liverpool: University of Liverpool

University of Liverpool Faculty of Arts (1937) The Liverpool School of Social Sciences and Administration including Departments of Economics, Commerce, Geography and Social Sciences. Prospectus of Courses Session 1937-18. Liverpool: University of Liverpool.

University of Manchester (1915) Prospectus of the Faculty of Arts. Session 1915-16. Manchester: University of Manchester

University of Manchester (1936) Prospectus of the Faculty of Arts. Session 1936-37. Manchester: University of Manchester 
University of Nottingham (1950) School of Politics, Economics and Social Sciences

Prospectus for the Session 1950-1. Nottingham: University of Nottingham

University of Nottingham (1954) School of Philosophy, Economics and Social Science Prospectus for the Session 1954-5. Nottingham: University of Nottingham.

University of Nottingham (1958) Board of Studies in Law and Social Sciences. March, 1950 to June, 1958. At University of Nottingham Archive ACC2278

University of Nottingham (1959) The Calendar of the University of Nottingham Session 1959-60. Nottingham: University of Nottingham

University of Nottingham (1964) The Calendar of the University of Nottingham Session 1964-65. Nottingham: University of Nottingham

University of Nottingham (1965) Faculty of Law and Social Sciences (Excluding the Degree of LL.B) Prospectus for the Session 1965-66. Nottingham: University of Nottingham

University of Oxford (1922) The Examination Statutes (statt. Univ. Oxon, Tit, Vi and parts Tot. II, V, Viii, and XII) revised to July 8, 1922 together with the regulations of the Boards of Studies and Boards of Faculties for Academic Year 1922-23. Oxford: OUP 
University of Sheffield (1968) Courses and General Information. Sheffield: University of Sheffield

University of St. Andrews (1939) The St. Andrews University Calendar for the Year 1939-1940. Edinburgh: William Blackwood and Sons Ltd.

University of Strathclyde (1969) General Information for Applicants. Glasgow:

University of Strathclyde

University of Sussex (1964) The University of Sussex Prospectus 1964/65. Brighton: University of Sussex

University College of Swansea (1961) Prospectus 1961-1962. Swansea: University College of Swansea

University of Wales (1898) The Calendar of the University of Wales for the Academic Year 1898-9. Newport: Mullock and Sons

University of Wales (1900) The Calendar of the University of Wales for the Academic Year 1900-1901.

University of Wales (1905) The Calendar of the University of Wales for the Academic Year 1905-6. Osestry: Woodall, Minshall, Thomas and Co and Caxton Press 
University of York (1969) Prospectus 1969-70. York: University of York

University of York (1970) Prospectus 1970-71. York: University of York.

Vout, M (1990) Oxford and the emergence of Political Science in England 1945-60. In:

P. Wagner et al (eds) Discourses on Society, 15: 163-91.

Wiseman, HV (1967) Introduction: Government, Politics and Political Science. In:

Wiseman HV (eds) Political Science: An outline for the intending student of Government, Politics and Political Science. London: Routledge and Kegan Paul, pp. 1-28.

Wokler, R (2001) The professoriate of political thought in England since 1914: a tale of three chairs. In: Castiglione D and Hampshire-Monk I (eds) The History of Political Thought in a National Context. Cambridge: Cambridge University Press, pp 134-158 